\title{
METHODOLOGY TO IDENTIFY AND ASSESS AGROECOLOGICAL PRACTICES IN METROPOLITAN AREAS. CASE STUDY, CONCEPCIÓN, CHILE
}

\author{
M. DELPINO-CHAMY, M. ALARCON, S. FERNÁNDEZ \& J. SOTO \\ University of Concepción, Chile.
}

\begin{abstract}
Urban agriculture (UA) is being constantly reviewed because of its significant contribution to urban and metropolitan sustainability (MS). Within the approaches associated with UA, agroecology stands out as a practice that places value on collaborative social networks. Emerging from grassroots organizations that focus on ecological production and food sovereignty, agroecology strengthens short production-consumption chains, therefore increasing the resilience of metropolitan systems, which are under constant threat by natural hazards. The focus of this research is to develop and apply a methodology that identifies underlying agroecological practices, describing their location, state of development, and potential contribution to sustainability within metropolitan areas. A theoretical framework is developed to distinguish agroecological practices from commonly practiced UA; subsequently a proposed methodology is developed to identify and assess these activities based on the following criteria: forms of production, sociopolitical organization, and MS. This methodological approach is used to analyze agroecological practices present in the Metropolitan Area of Concepción, Chile's second most important city, located over a territory with high presence of marshes, riverbeds, and wetlands. Conclusions identify as main strengths of agroecological practices their location on rururban interstices, together with their small scale of production; both aspects contribute to improving MS. Regarding weaknesses, the lack of appropriate planning policies and regulations threaten agroecological practices to disappear under the pressures exerted by contemporary urban development. Finally, particular attention should be given to associative organizations, which have proven to enhance sustainable agroecological outcomes, by increasing employment generation, environmental preservation and local resilience.

Keywords: Agroecology, metropolitan areas, metropolitan sustainability, rururban interstices, sociopolitical organization
\end{abstract}

\section{INTRODUCTION}

Metropolitan areas correspond to complex urban systems which are constituted through a set of closely related urban cores, forming a single multi-functional unit [1]. Their administrative structure, composed of different municipal entities; its gravitational weight as a result of the endogenous demographic growth; and the territorial expansion due to internal forces, are factors of complexity that increasingly stress the urban-rural relation in them, and struggle for revisions of the urban development model in pursuit of its sustainability [2]. In Latin America, the metropolitan areas concentrate $57 \%$ of the total population, and in the Chilean case there are 10 metropolitan centers recognized by territorial planning instruments (TPIs), such as Metropolitan Planning Schemes or Intercommunal Planning Schemes.

In many of these metropolitan areas, it is possible to observe the coexistence between purely urban activities and others of rural nature, such as agriculture. In most cases, this corresponds to a non-industrialized or medium-scale agriculture.

Various sectors around medium- or large-size cities are used for the development of agriculture, configuring rururban landscapes in the metropolitan borders, or in the interstitial spaces opened in the middle of the urbanized tissue [3]. These areas, in which small-scale agricultural practices are developed, coexist within few meters with urbanizations of different 
socioeconomic strata, road, or railway infrastructures, or industrial areas, configuring new forms of metropolitan periphery.

Due to the progress of urbanization over rural areas, associated to the economic growth of nations [4], cities, in general, and metropolitan areas, in particular, demand more and more agricultural products from distant territories. Therefore, some authors $[5,6]$ who define contemporary cities as socioecological systems (SESs) insist in the relevance of linking the social system with adjacent ecosystem resources in order to ensure their sustainability and resilience. However, several models of contemporary urban growth limit the self-subsistence capacity of SES, distancing consumers from food production centers. This makes cities vulnerable to shortages caused by natural or anthropic disasters, limiting their stability [7].

Consequently, the potential of rururban areas, still immersed in metropolitan urban tissues, offers enormous possibilities for the development of agriculture and strengthening of SES.

For the aforementioned reasons, this study is primarily focused on identifying and valuing agroecological practices developing in metropolitan rururban areas. Understanding sustainability is inherent to agroecology, through a constructivist approach [8].

On this basis, the article presents a methodological tool to assess the agroecological components of agricultural practices in metropolitan systems. Later it applies this tool and offers conclusions regarding the assessment of three representative cases studies in Concepción Metropolitan Area (CMA), discussing the strengths and weaknesses of these practices for the sustainability of the metropolitan SES.

\section{METROPOLITAN GROWTH AND GENERATION OF AGRICULTURAL PRACTICES IN RURURBAN TERRITORIES}

Contemporary metropolization processes are configured through several trends in urban development. On the one hand, a trend that promotes the suburban growth perpetuates the extension of the city over rural territories. These low-density real estate operations end-up configuring an urban system disperse and fragmented in the urban periphery [9]. On the other hand, the trend revitalizing sectors on the consolidated urban area is mainly based on operations which promote vitality and mixture of use through improvements on public space and high-density real estate operations [1].

Between these two tendencies - the low density suburban and the high density hyper-urban paradigms - it is possible to identify the existence of interstitial spaces that have remained halfway between one trend and the other. In the case of the metropolitan areas, "these act as a nexus, on occasions very blurred, between the compact city and the strictly rural territories located at greater distances," as Segrelles declares [4].

Complementary to these dynamics of growth, the topographic conditions of the territory are added. The presence of ravines and water bodies such as rivers, streams, or wetlands determines edge spaces, incapable of sustaining formal urban tissue, despite being often located in strategic areas within consolidated urban centers.

As a consequence of these phenomena of growth and metropolitan urban expansion over a certain geographical territory, a weakening and reduction of the peri-UA practices is observed in the old agricultural areas that surround the city. This results in the emergence of peri-UA practices (in the borders and periphery of the city) or interurban practices (in the interstitial spaces within the consolidated urban tissue) [3].

However, in the metropolitan urbanization processes, these territories both peri-urban and interstitial, suffer the most negative impact of the pressure of urban expansion. On the one hand, uses that fragment the old productive agricultural space that historically surrounded the 
cities are fostered [10]. On the other hand, pressures generated from real estate development, informal settlements, or the high price of the urban land, causes tensions and conflicts that end-up marginalizing the low-scale agricultural practices which are developed in these rururban areas $[4,11]$.

Consequently, the observation of the phenomenon of areas of rural vocation arises. These have been surrounded and absorbed by the processes of metropolitan urban growth, evidencing how most urban plans and regulatory schemes have been unable to prevent the conversion of rural lands into urban use [12].

Despite these regulatory limitations, UA has proven to offer great contributions to the sustainability of metropolitan urban systems. Proximity between agro-productive areas and consumers, involves a reduction of energy associated to distribution in transportation system, and mobility of citizens towards their supplying centers [13]. Complementarily, non-industrialized agricultural activity contributes with the greening of the city, generating microclimate and improving urban biodiversity [5,14], and local resilience [6,7].

Henceforth, reviewing agricultural practices in rururban areas, with emphasis on agroecological principles and food sovereignty criteria, arise as a strategic approach to improve metropolitan sustainability (MS).

\section{AGROECOLOGY AND FOOD SOVEREIGNTY AS STRATEGIC APPROACHES FOR THE STRENGTHENING OF URBAN SUSTAINABILITY}

Agroecology started to be studied in the 1970s as a response to the environmental, sociocultural, and economic crisis of the rural areas, as a consequence of the spread of industrial agriculture. It is associated with the concept of ecological agriculture, which is referred to as the application of ecological principles in order to develop sustainable agricultural ecosystems, with a minimal dependence on agrochemicals and external energy subsidies. Agroecology focused its analysis on agro-ecosystems and agro-food systems [15], promoting forms of collective and participative social actions, which encourage ecological food production and local commercialization strategies [16].

In the same manner, the research understands that sustainability is inherent to agroecology, through a constructivist approach [8]. This, unlike the conventional approach, not only includes new paradigms of economic, social, and environmental understanding, but also recognizes the need of local communities to discuss and decide on what they want to sustain, how and by whom.

Gomez et al. [8] and Gutiérrez et al. [17] mention four key conditions to consider agro-ecosystems sustainable: (i) they meet productive goals without compromising the organization of the systems in which they are supported; (ii) they do not depend on inputs foreign to their immediate surroundings; (iii) they are resilient and adaptable; and (iv) they can maintain social organization over time through equitable relations.

This vision is consistent with the principles stated in the Framework for Assessing Natural Resources Management Systems incorporating Sustainable Indicators (MESMIS), which in turn support the approaches of various researchers, such as Gutiérrez et al. [17] and González et al. [18]. MESMIS exhibits the following attributes for a sustainable agroecological practice: (i) productivity, (ii) stability, (iii) resilience, (iv) social equity, and (v) autonomy and cultural adaptability.

All these aforementioned criteria consider technical-productive stability and equitable social relations as key conditions of agroecological practices. Therefore, they strengthen the civil society as a leading agent of the productive and economic processes, for the sustainable organization of cities at both social and ecological scale [13]. 
Complementarily, special attention should be given to the concept of resilience, given that some authors, such as Álvarez-Salas et al. [19], Folke [5], and Collier et al. [6], have established the study of socioecological resilience, as an alternative to reach agroecosystems sustainability.

Finally, food sovereignty plays a key role in the theoretical approach of agroecology over the sustainability of metropolitan systems. Its conception arises from the farmers and base organizations articulated around the international movement La Vía Campesina, in 1993. And a decade later, in the International Forum on Food Sovereignty it was agreed to conceptualize food sovereignty as "the right of people to healthy and culturally appropriate food produced through ecologically and sustainable methods, and their right to define their own food and agriculture systems" [20].

The five pillars of food sovereignty, as defined by Ortega-Cerdà and Rivera-Ferre [21], in coherence with the Declaración de Nyéléni [20], consider: (i) access to resources, (ii) productive model, (iii) transformation and commercialization, (iv) food consumption and right to food, and (v) agricultural policies and organization of the civil society.

Thus, UA designed from an agroecological perspective and aimed to promote urban resilience and food sovereignty constitutes a novel element in the processes of reconstructing urban spaces, with significant sociocultural, environmental and urbanistic benefits [13].

\section{METHODOLOGY FOR THE EVALUATION OF AGROECOLOGICAL PRACTICES IN METROPOLITAN AREAS}

The proposed methodology is based on the dimensions provided by Soler and Rivera [13], for the design of agroecological indicators. Under this condition, the research analysis and cross methodological criteria defined by the following authors, in order to build an integrative assessment tool for agroecological practices in metropolitan areas: agroecological sustainability as defined by MESMIS; Gómez et al. [8] and Gutiérrez et al. [17] on their conditions to establish agro-ecosystem's sustainability; Ortega-Cerdà and Rivera-Ferre [21] with respect to food sovereignty; and the metropolitan considerations regarding resilience and urban sustainability, as defined by Navarro [3], Folke [5], and Collier et al. [6].

As a result, this study classifies the contributions of agroecological practices to the sustainability of metropolitan systems, under the following dimensions, criteria, and indicators:

\subsection{Category 1: Technical-Productive dimension}

Agroecology proposes a dialogue of acquaintance between the knowledge of farmers (entomology, botany, soils, and agronomy) and the scientific knowledge (analysis, evaluation, and sustainable management of agro-ecosystems) [16]. As a result of its application, an agroecological technical-productive approach decreases industrial inputs derived from oil, reduces long-distance transportation of foods and promotes the recovery and defense of local biodiversity [13]. Therefore, the assessment criteria defined for this dimension are:

\subsubsection{Criteria associated with FP}

FP. (1) Obtainment of water from natural sources: corresponds to the main natural resource for the development of agroecology. By guaranteeing that water can be reached in a close manner, it is possible to reduce costs of its acquirement and improve technology for its use in the entire agroecological process. 
FP. (2) Small-scale production: corresponds to the volume of production, considering three scales: seasonal intensive production; sporadic production which is carried out in some seasons of the year; and family self-consumption, which does not consider commercialization.

FP. (3) Low contamination and use of innocuous inputs: this is referred to both use of inputs and waste generated by the production, which do not contaminate basic resources such as soil, water, and air. The indicator suggests a limited use of agrochemicals, promotion of organic fertilizers, and natural reproduction of seeds.

FP. (4) Low technological level: mainly associated to the human and animal work, as well as traditional techniques of sowing, harvesting, cleaning, storing, and loading of agricultural products.

\subsection{Category 2: Sociopolitical dimension}

The political dimension of agroecology implies the construction of agro-food alternatives through collective actions, which could be related to production, commercialization, and even political struggle $[15,18]$. This is achieved from a social, ecological, and social perspective, to improve sustainable development of metropolitan systems. Therefore, agroecology is considered one of the central components of the social and solidarity economy, understanding it as a model of social relations where growth or money is not placed as the central axis of the development, but the relationships between people and communities. To reach this dimension, criteria related to socioeconomic organization of agroecological practices are defined as follows:

\subsubsection{Criteria associated with sociopolitics organizations (SO)}

SO. (1) Associativity: corresponds to the community forms of organization, which are related to the decision-making processes and the management of the land.

SO. (2) Permanence: it is referred to the existence of a family or community organization that can be maintained over time through equitable relationships that contribute to social reproduction.

SO. (3) Critical posture against the agro-industrial model: it is observed in cases in which producers are threatened in their way of production, which leads them to be informed in relation to benefits of the agro-industry to subsequently defend their position.

\subsection{Category 3: Urban Environment dimension}

The areas in which agroecological practices are developed can be conceived from the planning perspective, as zones of enjoyment and public recreation, by allowing the mixture with other land uses such as social equipment, park areas, and others [4]. This approach promotes a more harmonic territorial development in complex urban and large scale contexts such as the metropolitan ones. The integration of agriculture in urban environments also generates important social and ecological benefits by increasing local biodiversity and improving the resilience of the urban system [5,6]. The development of agricultural activity in the city is also a source of employment and incomes, which simultaneously favors the development of local production and consumption networks. Therefore, the integration of UA within a multifunctional strategy of soil use is consistent with recent strategy of urban sustainability [13]. To guarantee these outcomes, the urban environment criteria consider: 


\subsubsection{Criteria associated with MS}

MS. (1) Land use: diversity of uses, ownership of the land, and planning regulation applying over the studied territory.

MS. (2) Employment and distribution chains: corresponds to the generation of local jobs and the implementation of short production-commercialization chains.

MS. (3) Biodiversity: fulfillment of biodiverse productive goals without compromising the organization of the systems, from which the following aspects are supported: quality of soil, water, and biodiversity of the environment.

MS. (4) Resilience: in case of economic crisis or natural disasters, these areas have the capacity to provide food and water to the surrounding population.

\section{ASSESING AGROECOLOGICAL PRACTICES IN CMA, CHILE}

The study area corresponds to CMA, a major urban system of the Biobío Region, in central-southern Chile and second at national scale. It began to be configured in the middle of the 20th century with the industrialization of steel, which enhanced the conurbation between the regional capital, Concepción, and the port city of Talcahuano [1]. It is distinguished by its coastal and rainfed geography, flanked to the East by the Coastal Mountains. This consists of a complex water system composed of rivers Biobío and Andalién, as well as a set of lagoons and coastal wetlands. Administratively, it includes eleven (11) municipalities that house around one million inhabitants, in an area of $2,830.4 \mathrm{~km}^{2}$, which is equivalent to $12 \%$ of the surface of the Biobío Region. In total, seven (7) of these municipalities are littorals and four (4) are located in interior areas, concentrating $81 \%$ of the total population of the region.

In order to analyze the studied territory, Regulatory Planning Schemes of the CMA were georeferenced based on QGIS 2.0 software that run in Ubuntu operating system and based on the open-code GNU/Linux platform. Lately, agricultural land with a minimal surface of $145 \mathrm{~m}^{2}$ was mapped, based on the National Forestry Corporation cadastre from 2008. Complementing the georeference information with satellite images from Landsat, GNES/Astrium and Digital Globe, 2015 and 2016, available in Google Earth, a synthesis map was built, showing the existence of UA practices in CMA (see Fig. 1a).

Subsequently, satellite images were analyzed, experts were interviewed and field visits were carried out in order to identify invisible agroecological practices in the metropolitan area. Finally, three exemplary cases (Fig. 1b-d) were determined to be used as study elements in this research.

About the chosen study cases, the designed evaluation methodology was applied through the fulfilling of a file card for each one of the identified practices. This allowed the analysis of each dimension and criteria defined by the proposed methodology independently for each case. General results regarding the analysis of the three case studies are shown as follows:

\subsubsection{Criteria associated with the FP}

FP. (1) Obtainment of water from natural sources. All case studies are emplaced next to bodies of natural water, such as wetlands (in Case 1, Boca Sur), river (in Case 2, Cosmito), and a surface steam (in Case 3, Tome). However, only the two first cases obtain water from the natural sources, while Tome depends entirely on subsidies tank trucks and is just beginning to explore rainwater collection techniques. 


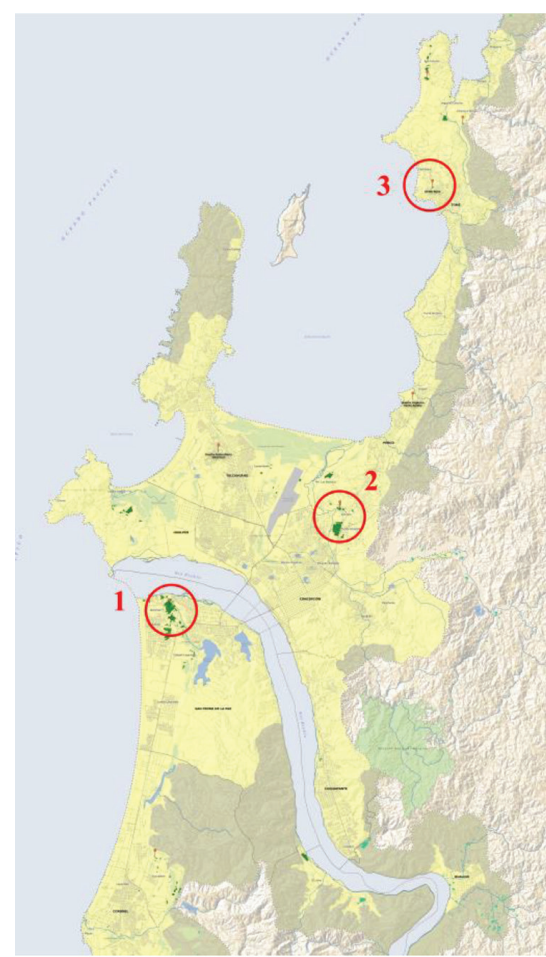

(a)

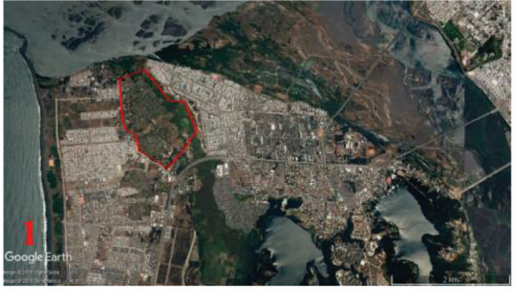

(b)

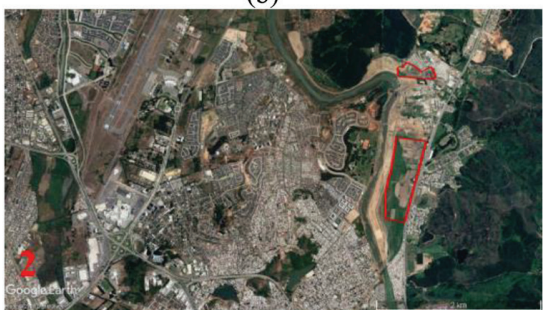

(c)

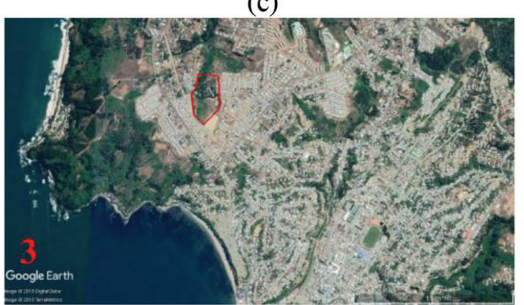

(d)

Figure 1: Map of the CMA and identification of study cases. (a) Concepción Metropolitan Area. (b) Case 1. San Pedro de la Paz, Boca Sur Sector. (c) Case 2. Penco/ Concepción, Cosmito Sector. (d) Case 3. Tomé, Los Lagos de Chile Sector.

FP. (2) Small-scale production. All three case studies presented production associated to family self-consumption scale. But only Case 1 in Boca Sur and Case 2 in Cosmito perform seasonal intensive production for commercializing.

FP. (3) Low contamination and use of innocuous products. In cases 1 and 3, a scarce application of agrochemicals and low dependence on fuels was observed, either due to the high cost of inputs and because they are considered unnecessary by the producers. Case 2 in Cosmito showed a significant use of agrotoxics to improve production.

FP. (4) Low technological level. In all cases, human and/or animal work was observed, as well as simple and collective techniques of sowing and harvesting.

\subsubsection{Criteria associated with SO}

SO. (1) Associativity. Farmers participating in Boca Sur and Tome belong to formal organizations, which allow them to establish links with other organizations of local producers and associativity with community and educational centers. Case 2 in Cosmito work under the subleasing of land.

SO. (2) Permanence. The case of Boca Sur is a result of the expansion of the urban tissue over rural areas, and had been used for agricultural practices for about 180 years. The case 
of Cosmito emerged as a Model Farm and has been used for agricultural purposes for approximately 120 years. In the case of Tomé, a more recent practice is observed, which is 20 years old. This was originated with the support of the NGO CET-South, with an environmental approach.

SO. (3) Critical position against the agro-industrial model. Both cases of Boca Sur and Tomé have developed diverse sociopolitical actions to protect surrounding wetland from the pressures of urban development and participate in activities of environmental training and seed bank. Cosmito case study functions under a productive logic and does not get involve in sociopolitical debates.

\subsubsection{Criteria associated to the MS}

MS. (1) Land Use. In both cases of Boca Sur and Cosmito, it is possible to identify ownership and leasing of the land. While Case 3 in Tome works on public land license by local council to be used by the social organization. Planning schemes only recognized Boca Sur as Productive Horticultural Zone (ZPH). Case 3 in Tome is regulated as Slope Lidding Zone (ZRES1). A particular situation is identified in Case 2, Cosmito, where two planning schemes overlap, regulating the land as Flood Area (ZEC3) over an Urban Extension for Residential Use (HE3).

MS. (2) Employment and distribution chains. All case studies evidence work valuation by farmers and their families, as well as fair prices in relation to the sales values in supermarkets of the surrounding. In general, the main destinations of the agricultural products were free markets around the local council area, such as Vega Monumental of Concepción, commercialized by intermediaries who buy directly from the farmers (Cases 1 and 2, Boca Sur and Cosmito). Sales to local stores are also performed by farmer's organizations, particularly by those in Boca Sur. In addition, the social organization of Case 3, Tome, sells and provide food to local institutions, such as schools and jails. Direct sales to final consumers are reduced because of being time-consuming.

MS. (3) Biodiversity: A high respect for biodiversity is observed in all practices analyzed, through the cultivation of species diversity (Case 3, Tomé), or the protection of flora and fauna of the water systems that sustain them (Case 1 and 2, Boca Sur and Cosmito).

MS. (4) Resilience: All cases studied, performed an important contribution in the event of the earthquake and tsunami of February 27, 2010. The studied organizations provided water and food to the surrounding communities. Along with this, it is known that in flood events, these areas have responded optimally, containing the floods of water courses.

\section{RESULTS FROM THE APPLICATION OF THE FP-SO-MS METHODOLOGY ANALYZING AGROECOLOGICAL PRACTICES IN CMA}

From field visits to each case study, together with the application of the proposed FP-SO-MS evaluation methodology, it has been possible to construct a synthesis table evidencing the contribution of the three agroecological practices analyzed in the CMA, to urban and territorial sustainability (see Table 1).

Out of this tool, it is possible to establish that the technical aspects associated with the FP yielded the best results within the analyzed case studies, mainly because of the small scale and low technological levels of production. SO demand a special review, yielding mediumto-high results, with Cosmito as a sensitive case study, showing a connection between associativity and critical position toward agro-industrial models. Finally, the criteria of land use associated with MS stand out with medium-to-low results, evidencing the need to improve 
Table 1: Synthesis of criteria for the evaluation of agroecological practices in the CMA.

\begin{tabular}{lccc}
\hline Indicator & $\begin{array}{c}\text { Case 1 } \\
\text { Boca Sur }\end{array}$ & $\begin{array}{c}\text { Case 2 } \\
\text { Cosmito }\end{array}$ & $\begin{array}{c}\text { Case 3 } \\
\text { Alto Tomé }\end{array}$ \\
\hline Form of production (FP) & & & \\
FP1. Obtaining water resources & A & A & C \\
FP2. Small-scale production & A & A & A \\
FP3. Innocuous inputs & A & B & A \\
FP4. Low technological level & A & A & A \\
Sociopolitical organization (SO) & & & \\
SO1. Associativity & A & B & A \\
SO2. Permanence & A & A & B \\
SO3. Critical position & A & C & A \\
Metropolitan Sustainability (MS) & & & B \\
MS1. Land Use & B & C & A \\
MS2. Employment and distribu- & A & B & \\
tion & & & A \\
MS3. Biodiversity & A & A & A \\
MS4. Resilience & A & A & \\
\hline
\end{tabular}

A, high; B, medium; C, low.

regulation policies and planning schemes, in order to protect the development of agroecological practices in metropolitan areas, strengthening their contribution to biodiversity, employment generation, and local resilience.

Toward the analysis of each dimension associated with the FP-SO-MS methodology, in CMA, it is possible to characterize the singularities of local agroecological practices with respect to their contribution to local sustainability.

\subsection{Regarding technical-productive dimension}

The strategic location inside the metropolitan area, assuring their proximity to water bodies, ensures the water self-sufficiency of the agroecological experiences analyzed. Family scale production and the use of innocuous inputs, associated to low contamination and humanscale technological levels, are elements of the agroecological practices that have shown to be contributing to the sustainability of the metropolitan system.

6.2 Regarding the sociopolitical dimension

A detailed analysis allows identifying an underlying relation between the origin of the studied initiatives, the associative structure that was adopted, and the effectiveness of the results associated to the proposed agroecology indicators. 
In two of the three experiences analyzed, the base organizations have become keys for the construction of associative networks, as well as a critical attitude towards the agro-industrial model. Furthermore, because of the existence of base organizations, agroecological experiences have been recognized by local public policies and incorporated into TPIs.

\subsection{Regarding the urban environment dimension}

At the same time, a positive input of agroecological practices to the MS is registered. This is evidenced throughout their contribution to employment generation, biodiversity, and short production-commercialization chains. Outstanding results are registered after the earthquake and tsunami of 2010, when these productive nodes contributed to the response to the social crisis of the urban system, providing basic products to surrounding communities, after the collapse of the road network.

Regardless of this contribution to local sustainability, regulatory planning schemes have been incapable of protecting these heritage practices, which are being threatened to disappear because of road infrastructural projects and expansion of residential areas.

\section{CONCLUSION: STRENGTHS, WEAKNESSES AND CRITICAL NODES OF AGROECOLOGICAL PRACTICES IN METROPOLITAN AREAS}

After applying the proposed FP-SO-MS methodology on three case study areas located in CMA, Chile, the study established that the main strengths of agroecological practices in metropolitan areas are related to their location in intersticial urban spaces, together with their non-industrialized scale of production.

The emplacement in rururban periphery and interstitial spaces determines a strategic location within the metropolitan system. On the one hand, these study areas correspond to non-urbanized spaces within the Consolidated Urban Area, favoring the creation of short supply chains out of the proximity between farmers and final consumers, as noted by Soler and Rivera [13]. On the other hand, their strategic location associated to water bodies inside the metropolitan area, allow them to act as a cushion for the sustainable dumping against flooding, and mass removal, increasing urban resilience and therefore confirming Calderon [7] and Colding and Barthel's studies [14].

Simultaneously, the main characteristics of agroecological practices, such as small-scale production and low levels of contamination, in addition to a critical posture regarding preservation of the environment, have proven to be factors enhancing the contribution of agroecological practices to local biodiversity, by preserving the ecosystem in which they are inserted as Folke [5], Colding and Barthel [14] predicted.

In terms of weaknesses, land use regulation and planning schemes are critical for improving urban sustainability [13]. Therefore, appropriate zoning such as agroparks, guaranteeing the protection of local food production could be a great contribution for the sustainability and resilience of the metropolitan SES [4-6]. Additionally, developing social infrastructure and equipment would contribute to the use of these edge spaces for social encounter, as proposed by Colding and Barthel, in their Urban Green Commons proposal [14] or Segrelles in his analysis of agroparks [4].

Base organizations have shown to be critical for the success and preservation of agroecological practices, becoming a key for strengthening food sovereignty throughout innocuous low-scale of production and the construction of collaborative networks [21], thus, reinforcing the thesis of Soler and Rivera [13], and the principles of agroecological practices [16]. 
A closer review to the results allows identifying the potential of agroecological organizations, enhancing local work, and production throughout the reinforcing of training activities, and improving selling capabilities of the farmers.

Finally, the FO-SO-MS methodology was proven to be successful for the quick assessment of agroecological practices in metropolitan systems, allowing one to compare different case studies, as well as identifying strengths and weaknesses to be addressed, in order to enhance their contribution to local sustainability. Regarding the methodology, further analysis can be performed by specifying a new set of quantitative indicators associated with each one of the proposed criteria.

Ultimately the study corroborates the importance of bringing up to date planning schemes, as well as strengthening civil society through agroecological practices in the CMA, as agents capable to lead productive, ecological and social processes. These strategies offer the mechanism to generate adequate proposals for the sustainable organization of metropolitan areas [13].

\section{REFERENCES}

[1] Rojas, C., Muñoz, I. \& García-López, M., Estructura urbana y policentrismo en el Área Metropolitana de Concepción. EURE., 35(105), pp. 47-70, 2009. https://doi. org/10.4067/s0250-71612009000200003

[2] Casado, G.G. \& Mielgo, A.A., La investigación participativa en agroecología: una herramienta para el desarrollo sustentable. Rev Ecosistemas [Internet], 6(1), 2007 Available from: http://revistaecosistemas.net/index.php/ecosistemas/article/ view/135\%5Cnhttp://www.redalyc.org/pdf/540/54016104.pdf

[3] Navarro, E. \& Álvarez, M.E., Agroecosistemas periurbanos, un potencial latente: Contribución al análisis de la multifuncionalidad a partir de indicadores de sustentabilidad. Revibec Rev Iberoam Econ ecológica, 24(0), pp. 107-21, 2015.

[4] Segrelles, J., Agricultura periurbana, parques naturales agrarios y mercados agropecuarios locales: Una respuesta territorial y productiva a la subordinación del campo a la ciudad. Scr, 19(502), pp. 1-35, November 2015.

[5] Folke, C., Resilience: the emergence of a perspective for social-ecological systems analyses. Glob Environ Chage 16, pp. 253-67, 2006.

[6] Collier, M., Nedovic-Budic, Z., Nedovic Budic, J., Aerts S., Connop D. \& Foley K., Transitioning to resilience and sustainability in urban communities. Cities, 32(1), pp. S21-8, 2013.

[7] Calderón, R., El rol de las Áreas Naturales Periurbanas para la Resiliencia al Cambio Climático de las Metrópolis: El Caso de la Ciudad de México. Rev Iberoam Econ Ecológica [Internet], 25(0), pp. 69-79, 2016. Available from: http://raco.cat/index.php/ Revibec/article/view/310591/400616

[8] Gomez. E.L., Concepto De Sostenibilidad En Agroecología.

[9] Borsdorf, A., Hidalgo, R. \& Sánchez, R., A new model of urban development in Latin America: The gated communities and fenced cities in the metropolitan areas of Santiago de Chile and Valparaíso. Cities, 24(5), pp. 365-78, 2007.

[10] Galindo, J. \& Giocoli, A., Los bordes de la ciudad metropolitana: apuntes para repensar la ciudad. QRU Quad Recer en Urban 2, pp. 100-17, 2013.

[11] Curzio de la Concha, C., El origen y las características de los fragmentos urbanopúblico residuales. Cuad Geográficos 42(1), pp. 53-82, 2008.

[12] UN-HABITAT., State of Latin American and Caribbean cities. Towards a New Urban Transition. United Nat. Naples, pp. 1-194, 2012. 
[13] Soler, M. \& Rivera, M., Agricultura, urbana, sostenibilidad y soberanía alimentaria: hacia una propuesta de indicadores desde la Agroecología. X Congr la Fed Española Sociol pp. 1-17, 2010.

[14] Colding, J. \& Barthel, S., The potential of 'Urban Green Commons' in resilience building of cities. Ecol Econ 86, pp. 156-66. 2013.

[15] Sevilla, E. \& Woodgate, G., Sustainable rural development: formal industrial agriculture to agroecology. In The International Handbook of Environmental Sociology, eds. M. Reddclift, and G.T. Woodgate, Cheltenham; 1997.

[16] Altieri. No Title.

[17] Gutiérrez, J., Aguilera, L. \& González, C., Agroecología y sustentabilidad. Converg Rev Ciencias Soci, 15(46), pp. 51-87, 2008.

[18] González de Molina, M. \& Caporal, F., Agroecología y política. ¿Cómo conseguir la sustentabilidad? Sobre la necesidad de una agroecología política. Agroecologia 8(2), pp. 34-43, 2013.

[19] Álvarez-Salas, L.M. \& Polanco-echeverry, D.N., Ríos-osorio L., Reflexiones acerca de los aspectos epistemológicos de la agroecología. Cuad Desarro Rural, 11(74), pp. 55-74, 2014.

[20] Foro Mundial sobre Soberanía Alimentaria. Declaración de Nyéléni [Internet]. 2007. Available from: https://nyeleni.org/spip.php?article290

[21] Ortega-Cerdà, M. \& Rivera-Ferre, M., Indicadores internacionales de Soberanía Alimentaria. Nuevas herramientas para una nueva agricultura. Rev Iberoam Econ Ecológica [Internet], 14, pp. 53-77, 2010. Available from: http://redibec.org/IVO/rev14_04.pdf 